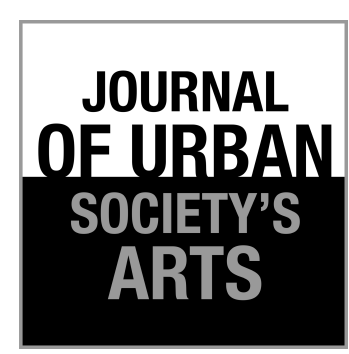

Volume 3 Nomor 2, Oktober 2016: 96-101

\section{Pengaruh Pariwisata pada Keberagaman Seni Rupa sebagai Modal Kultural Bali: Studi pada Komunitas dan Perhelatan Seni Rupa di Wilayah Denpasar, Klungkung, dan Singaraja}

Willy Himawan, Setiawan Sabana, dan A. Rikrik Kusmara

Fakultas Seni Rupa dan Disain, Institut Teknologi Bandung

Jl. Ganesha 10, Bandung

Tlp. 081322091008, E-mail: willyhim1302@gmail.com

\begin{abstract}
ABSTRAK
Pulau Bali terkenal sebagai salah satu tujuan wisata terbesar di dunia yang berkaitan erat dengan budaya Bali. Perkembangan seni rupa modern tidak dapat dipisahkan dari sejarah kolonialisme pada tahun 1900-an melalui pengembangan awal pariwisata yang memengaruhi perkembangan praktik seni Bali dan wacananya. Studi kualitatif ini akan melihat Bali sebagai kawasan-kawasan yang berbeda dalam spektrum perkembangan seni rupa yang dipengaruhi oleh konteks perkembangan pariwisata di tiap wilayah. Metode yang digunakan adalah aksi partipatoris di lapangan dengan pendekatan hermeneutik untuk memahami konteks, makna, dan nilai estetik yang terbangun dalam kegiatan-kegiatan seni rupa di Klungkung dalam kegiatan komunitas Batu Belah dalam acara Global Change Art Climate 2015, di Denpasar dan sekitarnya dalam kegiatan komunitas Sprites Art 2015, dan di Buleleng dalam kegiatan komunitas Segara Lor pada Buleleng Festival 2013. Perbedaan dalam konteks pengembangan pariwisata di daerah-daerah tertentu di Bali telah memengaruhi perkembangan dan perbedaan makna dan nilai estetika karya seni di sana.
\end{abstract}

Kata kunci: pariwisata Bali, modal kultural, Buleleng Festival, Segara Lor

\begin{abstract}
The Tourism Influence on Art Diversity as a Cultural Capital of Bali: Study on the Community and Art Events in Denpasar, Klungkung dan Singaraja. The island of Bali is famous as one of the largest tourist destination in the world. The development of modern art cannot be separated from the history of colonialism in the 1900s through the early development of Balinese art activities and their studies. This qualitative study sees Bali as different regions in the spectrum of the development of art which influenced by the context of the development of tourism in each region. The method used in this study is the action partipatoris field (participatory action field research) with a hermeneutic approach to understand the context, meaning, and aesthetic value that are built in the activities of art in Klungkung by among others are Batu Belah community in "The Global Change Art Climate 2015", in Denpasar "Sprites activities Art" in 2015, and in Buleleng in activities "Segara Lor in Buleleng Festival 2013". Differences in the context of the development of tourism in certain areas in Bali have influenced the development and meaning differences, and the aesthetic value of the works of art there.
\end{abstract}

Keywords: Bali tourism, cultural capital, Buleleng Festival, Segara Lor

\section{Pendahuluan}

Bali telah mengalami perubahan dalam sejarah yang panjang. Dalam buku Sejarah Bali Pra-Sejarah
Hingga Modern (Ardika, et.al. 2013) diungkap bahwa Bali merupakan suatu tempat/wilayah dengan perkembangan berbagai bentuk peradaban dalam kurun waktu yang sangat panjang. Melalui 
kajian terhadap artefak-artefak budaya serta sejarah, klasifikasi perkembangan budaya Bali terbagi dalam empat masa besar, yaitu masa prasejarah Bali, masa Bali Kuno, masa Bali Tengah, dan masa Bali Modern.

Pariwisata Bali, menurut Picard (2006) dimulai sejak runtuhnya kekuasaan Verenigde Oostindische Compagnie (VOC) yang diiringi dengan kokohnya kekuasaan Belanda terhadap Bali dan Nusantara bagian timur pada umumnya. Kenyataan bahwa Bali adalah wilayah yang berdasar pada kehidupan masyarakat yang menganut agama Hindu yang notabene berbeda dengan mayoritas masyarakat Indonesia. Suatu kenyataan bahwa Belanda kemudian hanya memiliki kekuasaan yang kokoh di Bali yang menyebabkan konservasi Bali adalah pertahanan yang kokoh bagi keberadaan Belanda di Indonesia. Pranata-pranata penunjang pariwisata yang telah dibangun Belanda sejak tahun 1914 telah menghidupi dan memberikan imaji yang baik bagi Belanda di mata internasional (Picard, 2006:30-32).

Sejak kurang lebih tiga dekade ke belakang, keberadaan pariwisata di Bali mengalami guncangan yang menyebabkan penurunan dan perubahan drastis dalam industri pariwisata, seperti yang digambarkan pada penurunan jumlah kunjungan selama setahun terakhir dalam data yang didapat Badan Pusat Statistik Provinsi Bali. Kondisi ini memunculkan pertanyaan mengenai identitas Bali di tengah kegalauan masyarakat Bali kini dan tindakan masyarakatnya beserta fenomena-fenomena sosial yang berkaitan dengan identitas, salah satu kebijakan pemerintah dengan mengetengahkan wacana "Ajeg Bali" (Bali yang stabil, tetap) mulai mengemuka di permukaan secara tajam dan kritis (Himawan 2014).

Fenomena mengenai Bali kini atau yang disebut sebagai identitas kultural di Bali muncul akibat adanya perubahan budaya yang terjadi

\begin{tabular}{cccccccc}
\hline \multirow{2}{*}{$\begin{array}{c}\text { Pintu } \\
\text { Masuk }\end{array}$} & $\begin{array}{c}\text { Januari } \\
\text { 2013 }\end{array}$ & $\begin{array}{c}\text { Januari } \\
\text { (Orang) }\end{array}$ & $\begin{array}{c}\text { Desember Jan 2013 } \\
\text { (Orang) }\end{array}$ & $\begin{array}{c}\text { Jan } 2013 \\
\text { (Orang) }\end{array}$ & $\begin{array}{c}\text { Thd } \\
\text { Des }(\%)\end{array}$ & $\begin{array}{c}\text { Thd Jan } \\
\text { 2012 }(\%)\end{array}$ & $\begin{array}{c}\text { Des Thd } \\
\text { Total Des } \\
(\%)\end{array}$ \\
\hline Bandara & 229.561 & 249.728 & 264.366 & $-13,17$ & $-8,08$ & 98,55 \\
Pelabuhan & 3.374 & 3.558 & 3.706 & $-8,96$ & $-5,17$ & 1,45 \\
Jumlah & 232.935 & 253.286 & 268.072 & $-13,11$ & $-8,03$ & 100,00 \\
\hline
\end{tabular}

Tabel 1. Kedatangan wisatawan mancanegara langsung menuju Bali menurut pintu masuk (Sumber: BPS, 2013) terutama akibat dunia pariwisata yang hampir menambah segala aspek kehidupan masyarakat Bali. Baik langsung maupun tidak langsung pariwisata telah memproduks citra mengenai Bali (Himawan 2014). Dalam satu dekade terakhir, perkembangan seni rupa Bali diwarnai oleh kegiatan-kegiatan komunitas seni rupa yang berasal dari daerahdaerah yang berbeda di Bali. Komunitas-komunitas tersebut dibangun oleh berbagai pihak, seperti akademisi, seniman, penggiat seni, dan pencinta seni, serta kadang kala kegiatan-kegiatannya mendapat dukungan (terutama dukungan dana) baik dari pihak swasta maupun pemerintah. Orang-orang yang terlibat dalam komunitaskomunitas seni rupa di Bali tersebut berkumpul terutama disebabkan oleh kesamaan daerah asal dan juga kedekatan dengan daerah-daerah tertentu. Terdapat beberapa komunitas seni rupa yang aktif dan cukup merepresentasikan konsep dan intensi yang dibangun komunitas melalui proses artistik dan keluasan sifat kegiatan-kegiatan yang telah dilakukan. Komunitas-komunitas tersebut adalah komunitas Batu Belah (yang kemudian menjadi Batu Belah Art Space) di daerah Lepang, Klungkung; komunitas Segara Lor di daerah Singaraja, Buleleng; dan komunitas Sprites Art (yang kemudian menjadi event dua tahunan - biennale dengan nama yang sama), di daerah Denpasar. Kegiatan yang ditinjau dalam studi ini adalah kegiatan "Global Change Art Climate" pada tahun 2015 yang diprakarsai oleh komunitas Batu Belah Art Space; kegiatan Buleleng Festival 2013 dengan keterlibatan komunitas Segara Lor dalam artistik besarnya (keseluruhan); dan kegiatan Sprites Art 2015.

Tujuan studi ini adalah untuk melihat kegiatankegiatan tersebut serta kaitannya dengan suasana serta perkembangan pariwisata di daerah tempat kegiatan berlangsung. Kegiatan-kegiatan tersebut di atas adalah kegiatan yang berlangsung belum

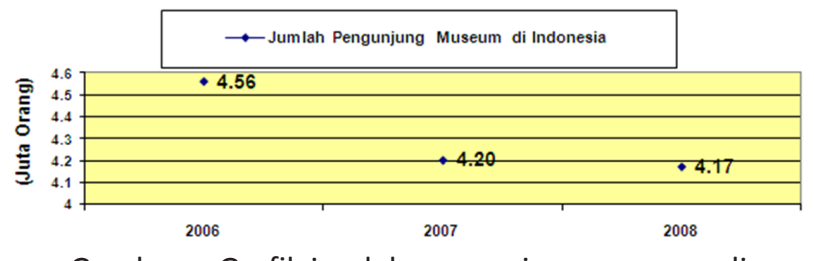

Gambar 1. Grafik jumlah pengunjung museum di Indonesia (Sumber: Depbudpar, 2009) 
lama (2013-2015), maka metode aksi partipatoris di lapangan, dalam istilah Bergold \& Thomas (2012) diperlukan untuk membangun pemahaman terhadap kegiatan yang telah berlangsung dalam kerangka mengalami kegiatan yang berlangsung. Pemahaman terhadap suasana dan perkembangan pariwisata di daerah-daerah tempat kegiatan berlangsung memerlukan pendekatan hermeneutik dan kesejarahan untuk dapat memetakan keadaan.

\section{Pembahasan}

$\begin{array}{cccc}\text { Dalam studinya Pertiwi } & \text { (2012) } \\ \text { mengungkapkan bahwa kebijakan } & \text { yang } \\ \text { mengetengahkan keunggulan potensi alam, }\end{array}$
terutama pantai, telah mengakibatkan terjadinya ketimpangan perkembangan kawasan, terutama yang sangat menonjol adalah perkembangan wilayah Bali Selatan, meliputi Sanur, Kuta, dan Nusa Dua, yang memiliki pantai dengan pasir putih dan telah mengalami perkembangan yang sangat pesat dan bahkan kini terlalu berlebihan dibandingkan dengan kawasan lain di wilayah Bali. Wilayah Bali Tengah masih dapat menyamai Bali Selatan, walau tidak sepesat perkembangan Bali Selatan. Sisi lain wilayah Bali utara, menurut Pertiwi (2012) telah mengalami fase stagnan dan bahkan menuju fase decline.

Sebagai keunggulan baru, kegiatan kesenian dalam Perda No. 2 tahun 2012 tentang kepariwisataan Bali memiliki posisi yang kuat dan mulai mendapat perhatian dalam pandangan kepariwisataan Bali. Sebagai bagian dari budaya Bali kini, perkembangan komunitas-komunitas seni rupa khususnya, dan komunitas-komunitas seni

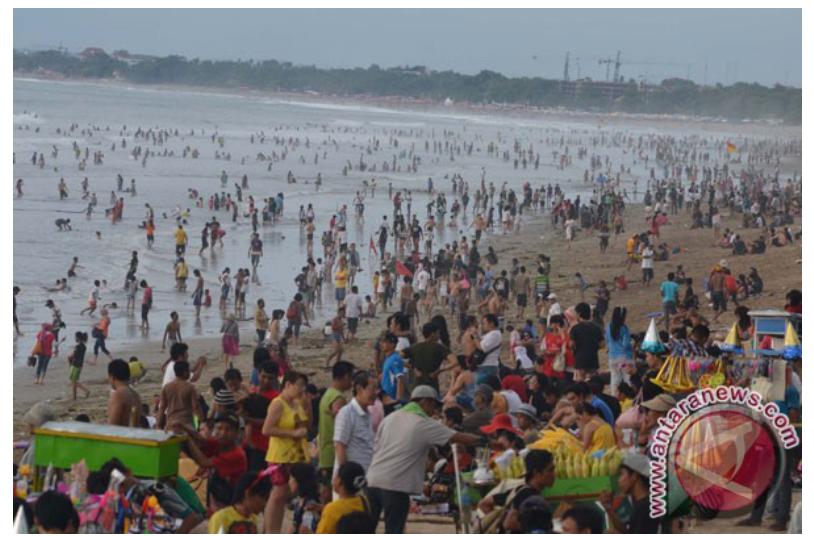

Gambar 2. Daerah pantai Kuta pada umumnya menjadi suatu bentuk representasi baru dari budaya Bali itu sendiri.

Komunitas-komunitas seni yang dilihat dalam studi ini adalah Batu Belah (yang kemudian menjadi Batu Belah Art Space) di daerah Lepang, Klungkung, dengan figurnya I Wayan Sujana "Suklu" yang merupakan sosok akademisi yang berasal dari Sekolah Tinggi Seni Indonesia (STSI) Denpasar (kini ISI Denpasar); komunitas Segara Lor di daerah Singaraja, Buleleng, dengan figurnya I Wayan Sudiarta, lulusan Sekolah Tinggi Keguruan dan Ilmu Pendidikan (STKIP) Singaraja (kini Universitas Ganesha - Undiksha Singaraja); dan komunitas Sprites Art (yang kemudian menjadi event dua tahunan - biennale dengan nama yang sama), di daerah Denpasar sekitarnya dengan figurnya Yoka Sara, seorang arsitek terkenal Bali lulusan Universitas Udayana Bali.

"Global Change Art Climate" pada tahun 2015 diprakarsai oleh komunitas Batu Belah Art Space. Komunitas Batu Belah merupakan komunitas yang memulai kegiatannya sejak tahun 2007 dengan mengetengahkan konsep mengenai tanggung jawab sosial dari proses kreasi para seniman terhadap masyarakat sekitar. Kegiatan "Global Change Art Climate" ini merupakan kegiatan seni rupa yang juga melibatkan bentuk kesenian lain seperti instalasi seni, seni pertunjukan, sastra, dan musik. Kegiatan ini mendapat dukungan Direktorat Pengembangan Kesenian dan Perfilman, Kemendikbud Republik Indonesia dan juga wilayah daerah kecamatan Desa Takmung Klungkung. Acara puncak kegiatan ini dilaksanakan pada 30 Mei 2015, di Pantai Lepang, dengan digelar bentukbentuk karya seni rupa instalasi yang lebih banyak

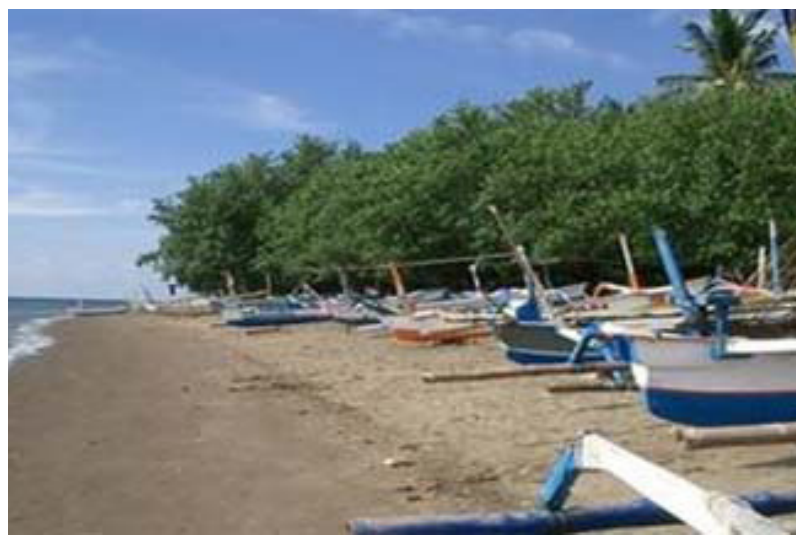

Gambar 3. Pantai Lovina Buleleng, Bali Utara 
mengkritik keberadaan pembangunan infrastruktur kepariwisataan seperti resort, hotel, dan kondotel yang dinilai oleh seniman-seniman yang terlibat sebagai pengekploitasian terhadap alam. Salah satunya adalah bentuk seni rupa instalasi "Not For Sale" karya Nano u Hero.

Buleleng Festival 2013 melibatkan komunitas Segara Lor dalam artistik besarnya (keseluruhan). Buleleng Festival merupakan kegiatan rutin tahunan Pemerintah Kabupaten (Pemkab) Buleleng yang bertujuan untuk membangkitkan kembali budaya lokal dan budaya kreatif kontemporer daerah Buleleng dan menjadikannya sebagai kebanggaan baru daerah Buleleng. Keterlibatan komunitas Segara Lor yang diprakarsai oleh I Wayan Sudiarta, dimulai sejak perhelatan pertama Buleleng Festival tahun 2012 dengan mengadakan pameran seni rupa dalam perhelatan besar Buleleng Festival 2012. Pada tahun 2013, komunitas Segara Lor dipercaya oleh Pemkab Buleleng sebagai tim artistik keseluruhan acara. Komunitas Segara Lor adalah komunitas yang sebagian besar terdiri dari alumnus Jurusan seni rupa Undiksha Singaraja. Komunitas ini telah mengadakan berbagai pameran yang menunjukkan perkembangan artistik yang terjadi terutama di daerah Buleleng, yang memiliki karakteristik berbeda dengan wilayah Bali lainnya, dengan mengetengahkan perpaduan antara estetika tradisi dengan keadaan kontemporer wilayah Buleleng yang secara geososial memiliki budaya yang cenderung beragam dibandingkan wilayah Bali lainnya. Hal ini dikarenakan oleh

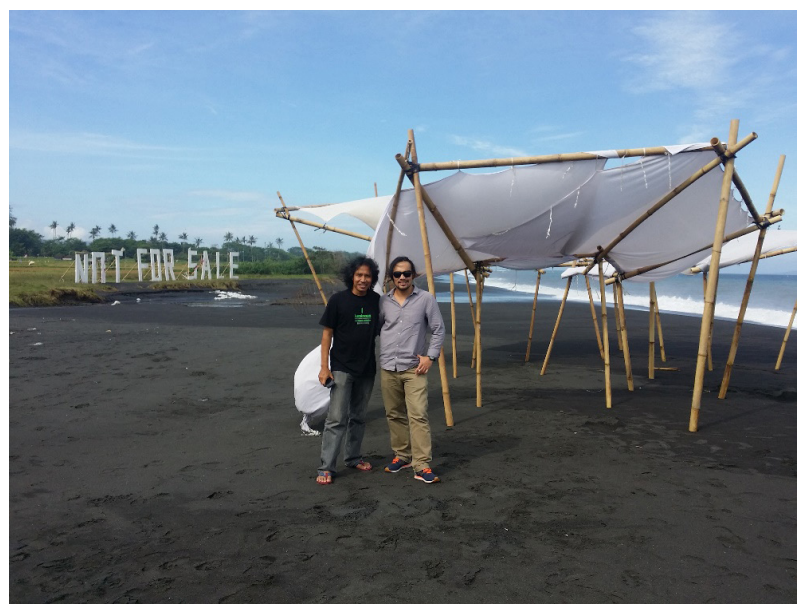

Gambar 4. Penulis dan Wayan Sujana "Suklu" di depan karya instalasi di Pantai Lepang (Sumber: Dokumentasi penulis) sejarah daerah Buleleng, seperti disebutkan oleh Lombard (1996), yang melihat daerah Buleleng pada era sebelum kolonialisme dan juga pada era kolonialisme menjadi pintu masuk ke Pulau Bali melalui pelabuhan-pelabuhannya seperti Pelabuhan Singaraja, Pelabuhan Sangsit dan daerah Tejakula. Dalam perhelatan Buleleng Festival tahun 2013, komunitas Segara Lor mengetengahkan karya-karya seni rupa yang bersifat dekoratif sebagai bagian besar dari bentuk artistik perhelatan ini. Hal ini dikarenakan adanya keinginan akomodatif Pemkab Buleleng sendiri terhadap struktur Buleleng Festival sebagai tujuan pariwisata.

Sprites Art 2015 berlangsung Juni - awal September 2015 di wilayah Sanur Bali. Kegiatan ini didukung oleh Yayasan Nithyakala, Yayasan Pembangunan Sanur, dan Sanur Village Festival. Kegiatan Sprites Art merupakan kegiatan dua tahunan yang dimulai sejak 2013, yang mengambil tema besar "Earth" atau "Tanah", dan untuk perhelatan Sprites Art 2015 mempunyai tema besar yaitu "Water" atau "Air". Kedua tema besar yang telah berlangsung ini merupakan bagian dari lima unsur utama kosmologi Bali, yaitu terdiri dari "tanah", "air", "angin", "cahaya”, dan "udara”.

Kegiatan Sprites Art 2015 merupakan kegiatan yang melibatkan berbagai bentuk kesenian dan juga puluhan seniman. Kegiatan ini juga merupakan kegiatan yang terintegrasi dengan kegiatan besar lain yang telah menjadi daya tarik pariwisata yaitu Sanur Festival. Penyelenggaraan dipenuhi oleh berbagai macam jenis kegiatan seni rupa, seperti

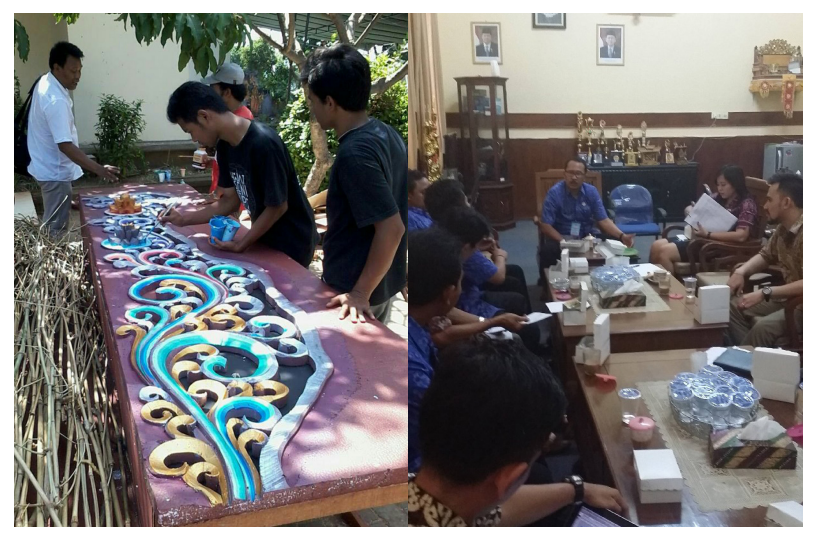

Gambar 5. I Wayan Sudiarta mengawasi pembuatan karya seni dekoratif untuk Buleleng Festival 2013 (kiri), Penulis bersama I Wayan Sudiarta mengikuti rapat Buleleng Festival 2013 di kantor Bupati Buleleng (kanan). (Sumber: Dokumentasi penulis) 

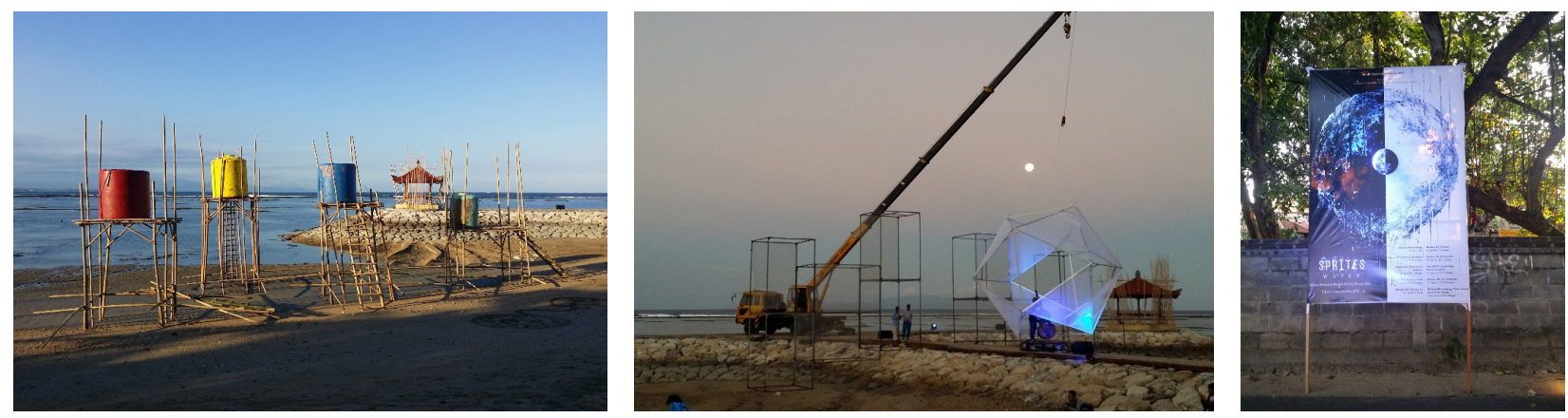

Gambar 6. (kiri ke kanan) Karya instalasi Wayan Upadana, karya instalasi-arsitektur dengan melibatkan crane dan video mapping, baliho kegiatan.(Sumber: Dokumentasi penulis)

melukis di atas tubuh (body painting), pertunjukan kontemporer dalam tari-tari kontemporer, pertunjukan digital pada video mapping, dan seni rupa instalasi dengan melibatkan alat berat (crane). Penampilan pemusik genre jazz juga menjadi suatu ekspresi yang kolaboratif antarseniman.

Dalam melakukan aksi partisipatoris di lapangan, studi ini melihat keberadaan kegiatan dengan berbagai bentuk karya seni, konsep, dan kaitan jejaring yang berada di dalam masing-masing kegiatan. Pada saat yang sama, sebagaimana sikap pendekatan aksi partisipatoris di lapangan, juga melihat dan mengambil jarak terhadap hubungan antara keberadaan pariwisata di daerah tempat pelaksanaan kegiatan itu sendiri dilaksanakan (Gambar 7).

Dalam gambar 7 dapat dilihat tiga titik berwarna merah, kuning, dan hijau. Warna merah menunjukkan tempat pelaksanaan kegiatan Sprites Art 2015, di wilayah Sanur dengan perkembangan pariwisata yang pesat dan sudah terbentuk. Warna merah dipilih dengan pertimbangan psikologi umum terhadap warna yang membangun emosi yang kuat, meningkatkan hasrat, dan menunjukkan cinta (Kristina 2012). Warna kuning juga dipilih berdasarkan pertimbangan psikologi umum

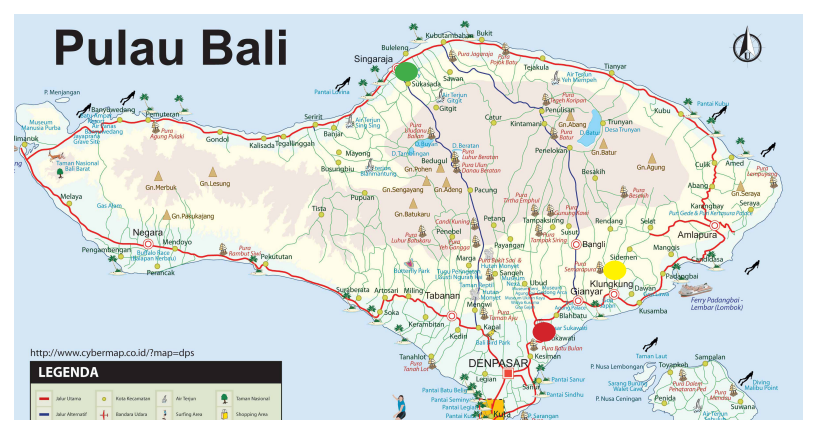

Gambar 7. Peta pulau Bali dan titik pelaksanaan kegiatan (Sumber: Peta google maps) terhadap warna yang menunjukkan suatu keriahan, namun bersifat melelahkan mata. Warna kuning merupakan tempat pelaksanaan "Global Change Art Climate" pada tahun 2015. Warna kuning sesuai dengan perkembangan pariwisata daerah Bali Tengah yang selalu ingin menyeimbangkan diri terhadap perkembangan pariwisata daerah Bali Selatan, namun seringkali tidak mampu dan mengalami kelelahan oleh karena stabilitas dan kekuatan infrastruktur pariwisata di daerah Bali Selatan.

Hal yang sama juga digunakan dalam pemilihan warna hijau yang merupakan gabungan dari warna biru dan kuning. Biru memiliki sifat yang lebih tenang dengan kecenderungan rasa sepi. Seperti halnya perkembangan pariwisata di daerah Bali Utara sebagai tempat penyelenggaraan kegiatan Buleleng Festival 2013, daerah Bali Utara tidaklah sepi dan setenang representasi warna biru sehingga warna hijau dipilih untuk merepresentasikan keadaan pariwisata di daerah tersebut.

\section{Simpulan}

Berdasar atas studi ini dapat disimpulkan bahwa Bali adalah pulau yang dihidupi oleh budaya homogen Hindu Bali, namun perkembangan yang berbeda-beda pada aspek kepariwisataan telah berpengaruh pada perkembangan yang berbeda-beda juga dalam kegiatan seni rupa. Hal ini kemudian memperlihatkan perbedaan pandangan, nilai, dan konsep dalam ekspresi seni rupa yang dihasilkan. Daerah yang memiliki perkembangan pariwisata yang sudah kuat dan stabil memungkinkan terjadinya peristiwa/ perhelatan seni yang masif dengan jejaring yang 
sangat memadai. Ekspresi seni yang dihasilkan pun beragam, lebih kontemporer dengan kenyamanan masing-masing seperti tampak dalam perhelatan Sprites Art 2015. Daerah pariwisata yang sedang berkembang dan berdekatan dengan daerah pariwisata yang sudah stabil menghasilkan ekspresi seni yang lebih memiliki nilai kritik terhadap pariwisata, terutama terhadap pembangunan infrastruktur dan efek-efek sosial dari pariwisata itu sendiri, seperti tampak dalam perhelatan Global Change Art Climate 2015. Sementara itu, daerah pariwisata yang cenderung belum berkembang dan ingin berkembang, menghasilkan ekspresi seni yang cenderung lebih dekat dengan keberadaan budaya asal (tradisi) dalam bentuk-bentuk dekoratif yang memang dapat ditemukan pada budaya tradisi seperti dalam perhelatan Buleleng Festival 2013. Diversifikasi ekspresi seni rupa ini adalah merupakan modal kultural tersendiri yang dapat dimanfaatkan oleh Bali pada kemudian hari.

\section{Ucapan Terima Kasih}

Penulis mengucapkan terima kasih kepada panitia 7 th Digital Information \& System Conference (DISC) yang telah memberi kesempatan untuk menyajikan artikel ini dalam panel "Menyongsong Masyarakat Ekonomi Asean Melalui Penguasaan Dalam Seni, Budaya, Pendidikan, dan Teknologi 2015” di Universitas Kristen Maranatha Bandung. Terima kasih juga disampaikan kepada I Wayan Sujana, M.Sn atas bantuan pengamatan lapangan; I Wayan Sudiarta, S.Pd., M.Si. atas dukungan data dari Buleleng; Bapeda Tk. II Buleleng atas data penyelenggaraan Buleleng Festival 2013; dan Mitra Bebestari Journal of Urban Society's Art yang telah memberi masukan untuk perbaikan tulisan ini.

\section{Kepustakaan}

Ardika, I.W., Parimartha, I.G. \& Wirawan, A.A.B., 2013. Sejarah Bali: dari prasejarah hingga modern. Denpasar: Udayana University Press.

Bergold, J. \& Thomas, S., 2012. "Participatory Research Methods: A Methodological Approach in Motion”. Forum Qualitative Social Research, Volume 13 (No. 1, Art. 30 January), pp.10-33. Available at: http://www. qualitative-research.net/index.php/fqs/article/ view/1801/3334. Accessed December 2013.

BPS, B., 2013. Berita Resmi Statistik BPS Provinsi Bali No. 15/03/., Denpasar, Bali: BPS Propinsi Bali.

Depbudpar, 2009. Pusat Pengelolaan Data dan Sistem Jaringan, Jakarta: Depbudpar.

Himawan, W., 2014. "Citra Budaya Melalui Kajian Historis dan Identitas: Perubahan Budaya Pariwisata Bali Melalui Karya Seni Lukis". Journal of Urban Society's Arts, Volume 1(No. 1-April), pp.74-89.

Kristina. 2012. Infographic: The Psychology of Color. Wordpress. Available at: http:// paintersoflouisville.com/the-psychology-ofcolor/.

Lombard, D., 1996. Nusa Jawa: Silang Budaya, Kajian Sejarah Terpadu. Bagian I: Batas-Batas Pembaratan. Jakarta: PT Gramedia Pustaka Utama.

Pertiwi, P.R., 2012. Pola Perencanaan \& Pengembangan Kawasan Lovina, Wilayah Bali Utara, Perencanaan Pariwisata Program Pasca Sarjana Kajian Pariwisata (DDIP), Denpasari: Udayana University Press.

Picard, M., 2006. Bali: Pariwisata Budaya dan Budaya Pariwisata. Jakarta: KPG. 